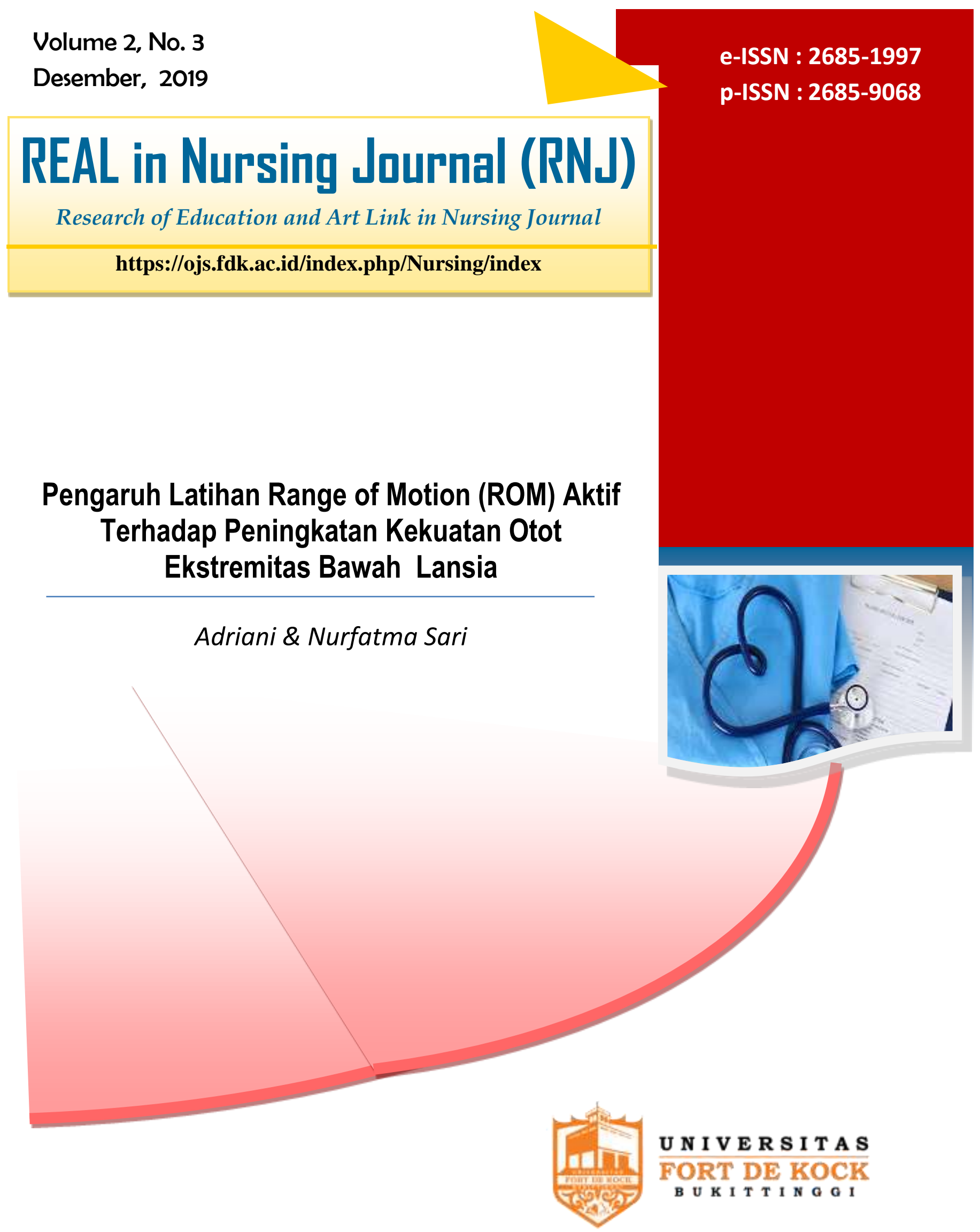

Program Studi Keperawatan dan Pendidikan Ners Universitas Fort de Kock Bukittinggi, Indonesia 


\section{Pengaruh Latihan Range of Motion (ROM) Aktif Terhadap Peningkatan Kekuatan Otot Ekstremitas Bawah Lansia}

\begin{tabular}{c}
\hline REAL in \\
Nursing \\
Journal (RNJ) \\
https://ojs.fdk.ac.id/inde \\
x.php/Nursing/index \\
\hline
\end{tabular}

Keywords:

elderly, muscle strength, range of motion

Korespondensi:

Adriani

adrianisuwito@fdk.ac.id

Prodi Keperawatan dan
Ners, Universitas Fort De
Kock Bukittinggi

\author{
Adriani \& Nurfatma Sari
}

\begin{abstract}
Musculoskeletal system disorders of weakness in the muscles of the elderly are common. Actions that can be taken to reduce complaints of the elderly are with range of motion (ROM) exercises. The purpose of this study was to determine the effect of active range of motion (ROM) exercises on increasing the strength of lower limb muscles in the elderly. Preexperimental research design with one group pre-test and post-test. By means of purposive sampling with 6 respondents. Giving intervention as much as 6 times exercise for 3 weeks with a frequency of 2 times a day ie for 10 minutes with 3 repetitions of movements. Analysis was performed by paired dependent $T$-test samples. The results showed that the average lower limb muscle strength in the elderly before active ROM exercises were the hip region $=3.03317$, the knee region $=3.44433$, the ankle region $=$ 3.24300 , the toe region $=3.31950$. While the average lower limb muscle strength after active ROM exercises are the hip region $=3.22117$, knee region $=3.76367$, ankle region $=3.51383$, toe area $=3.86800$, with hip value $p=0.028$, knee $p=0.002$, ankle $p=0.002$, toe $p=0,000$. Based on the results of the study it can be concluded that there is an effect of active range of motion (ROM) exercises on increasing muscle strength in the elderly. This research is expected to be a consideration for the elderly orphanages in order to make the range of motion (ROM) as an exercise program to increase muscle strength in the elderly.
\end{abstract}

\section{ABSTRAK}

Gangguan system muskuloskeletal kelemahan pada otot-otot lansia lazim terjadi, Tindakan yang dapat dilakukan untuk mengurangi keluhan lansia adalah dengan latihan range of motion (ROM). Tujuan penelitian ini untuk mengetahui pengaruh latihan range of motion (ROM) aktif terhadap peningkatan kekuatan otot ekstremitas bawah pada lansia .Desain penelitian pra eksperiment dengan one group pre test dan post test. Dengan cara pusposive sampling dengan 6 responden. Pemberian intervensi sebanyak 6 kali latihan selama 3 minggu dengan frekuensi 2 kali dalam sehari yaitu selama 10 menit dengan 3 kali pengulangan gerakan. Analisis dilakukan Paired sampel T-test dependent. Hasil penelitian didapatkan rata-rata kekuatan otot ekstremitas bawah pada lansia sebelum latihan ROM aktif adalah regio hip $=3,03317$, regio knee $=3,44433$, regio ankle $=$ 3,24300 , regio toe $=3,31950$. Sedangkan rata-rata kekuatan otot ekstremitas bawah setelah latihan ROM aktif adalah regio hip $=3,22117$, regio knee $=3,76367$, regio ankle $=3,51383$, regio toe $=3,86800$, dengan nilai hip $p=0,028$, knee $p=0,002$, ankle $p=0,002$, toe $p=0,000$. Berdasarkan hasil penelitian dapat disimpulkan terdapat pengaruh latihan range of motion (ROM) aktif terhadap peningkatan kekuatan otot lansia. Penelitian ini diharapkan bisa menjadi pertimbangan bagi panti asuhan Lansia agar bisa menjadikan range of motion (ROM) sebagai program latihan untuk meningkatkan kekuatan otot pada lansia.

Kata Kunci : asupan gizi, pola asuh, stunting 


\section{PENDAHULUAN}

Lanjut usia adalah bagian dari proses tumbuh kembang. Manusia secara tiba tiba menjadi tua, tetapi berkembang dari bayi, anak anak, dewasa dan akhirnya menjadi tua. Hal ini normal, dengan perubahan fisik dan tingkah laku yang dapat diramalkan yang terjadi pada semua orang pada saat mereka mencapai usia tahap perkembangan kronologis tertentu (Azizah, 2011: Sahmad et al, 2016). Menjadi tua adalah suatu proses yang tidak dapat dihindari oleh kita semua, namun tidak ada pengaruh antara penilaian ciri menjadi tua itu dengan kesehatan (Stanley \& Beare, 2007, p.4). Dalam Buku Ajar Geriatri, Prof. Dr. R. Boedhi Darmojo dan Dr. H. Hadi Martono (1994) mengatakan bahwa "menua" (menjadi tua) adalah suatu proses menghilangnya secara perlahan kemampuan jaringan untuk memperbaiki diri/ mengganti diri dan mempertahankan struktur dan fungsi normalnya sehingga tidak dapat bertahan terhadap jejas dan memperbaiki kerusakan yang diderita (Nugroho, 2008, p.11).

Menurut WHO tentang kesejahteraan lanjut usia pada pasal 1 ayat 2 yang menyebutkan bahwa umur 60 tahun adalah usia permulaan tua. Menua bukanlah suatu penyakit, akan tetapi merupakan proses yang berangsur angsur mengakibatkan perubahan yang kumulatif, merupakan proses menurunnya daya tahan tubuh dalam menghadapi rangsangan dari dalam dan luar tubuh yang berakhir dengan kematian (Padila, 2013, p.6). Jumlah penduduk usia lanjut pada tahun 2015 adalah sebanyak 900 juta jiwa. Jumlah ini setara dengan $12 \%$ dari jumlah penduduk dunia. Sementara itu di Asia, terdapat sejumlah 508 juta penduduk berusia lanjut. Angka ini menunjukkan bahwa jumlah penduduk lanjut usia di Asia menyumbang lebih dari setengah jumlah lansia di seluruh dunia. (United Nations, 2015 : Depkes RI, 2015).

Di Indonesia batasan usia lanjut adalah 60 tahun ke atas, terdapat dalam UU No 13 tahun 1998 tentang kesejahteraan lanjut usia. Menurut UU tersebut diatas lanjut usia adalah seseorang yang mencapai usia 60 tahun ke atas, baik pria maupun wanita (Padila, 2013. p.6). Jumlah lansia di Indonesia pada tahun 2020 diperkirakan menjadi 11,34\%. Menurut data BPS tahun 2015 presentase estimasi penduduk lansia di Indonesia sebanyak $8,5 \%$. Provinsi dengan presentase lansia tertinggi adalah DI Yogyakarta (13,4\%) dan terendah adalah Papua (2,8\%). Peningkatan proporsi jumlah lansia tersebut perlu mendapatkan perhatian karena kelompok lansia merupakan kelompok beresiko tinggi yang mengalami berbagai masalah kesehatan khususnya penyakit degeratif (Kemenkes RI, 2015).

Di Sumatera Barat, hasil sensus penduduk pada tahun 2014 jumlah penduduk lanjut usia adalah 5.131 .882 jiwa, sedangkan pada tahun 2015 terdapat 5.196.370 jiwa penduduk dengan laju pertumbuhan penduduk per tahunnya adalah $1.26 \%$ dengan angka tertinggi di Padang yaitu 902.413 jiwa penduduk (BPS, 2015). Penurunan fungsi dan kemampuan tubuh pada lansia akan menurun begitu pula dengan kekuatan otot akan menurun seiring dengan pertambahan usia. Pada seorang lanjut usia akan membawa perubahan yang menyeluruh pada fisiknya yang berkaitan dengan menurunnya kemampuan jaringan tubuh terutama pada fungsi fisiologis dalam sistem musculoskeletal dan system neurologis (Padila, 2013, p.56).

Peubahan normal akibat penuaan ini paling jelas terlihat pada sistem muskuloskeletal berupa penurunan otot secara 
keseluruhan pada usia 80 tahun mencapai 30\% sampai $50 \%$. Hambatan mobillitas yang diakibatkan oleh perubahan patologis pada sistem muskuloskeletal berupa penurunan kekuatan dan ketangkasan otot, kontraktur yang membatasi mobilitas sendi, kekakuan dan nyeri pada sendi (Uda et al, 2016).

Selain perubahan fisiologis, lansia juga mengalami perubahan morfologis. Dampak perubahan morfologis otot adalah penurunan kekuatan otot, penurunan fleksibilitas, dan penurunan kemampuan fungsional otot. Kekuatan otot pada lansia akan berkurang sebanyak 10- $15 \%$ tiap minggunya dan sebanyak $5,5 \%$ dapat hilang setiap hari pada kondisi istirahat dan mobilitas sepenuhnya (Stanley \& Beare, 2007, p. 157). Kekuatan otot adalah tenaga kontraksi otot yang dicapai dalam sekali usaha maksimal. Usaha maksimal ini dilakukan oleh otot atau sekelompok otot untuk mengatasi suatu tahanan. Kekuatan otot secara umum adalah kekuatan sistem otot secara keseluruhan dalam mengatasi suatu tahanan (Atmojo, 2008 : Mudrikhah, 2012).

Penurunan fungsi musculoskeletal pada lansia dengan kelemahan fisik dapat menurunkan aktivitas fisik (physical activity) dan latihan (exercise), sehingga akan mempengaruhi lansia dalam melakukan aktivitas kehidupan sehari-hari (activity daily living). Untuk mencegah perubahan lebih lanjut, dapat diberikan latihan untuk mempertahankan mobilitas (Pudjiastuti \& Utomo, 2003, p.10). Hal yang dapat Anda lakukan adalah mencegah atau meminimalkan dampak penurunan kekuatan otot. Intervensi yang bisa dilakukan pada orang tua adalah dengan latihan fisik. Ada beberapa latihan fisik untuk orang tua, yaitu latihan isotonik dan isometrik, latihan aerobik, dan latihan Range of Motion (ROM) (Safa"ah et al, 2017).

Range of Motion (ROM) dapat diartikan sebagai pergerakan maksimal yang dimungkinkan pada sebuah persendian. Rentang pergerakan sendi bervariasi dari individu ke individu lain dan ditentukan oleh jenis kelamin, usia, ada atau tidaknya penyakit, dan jumlah aktivitas fisik yang normalnya dilakukan seseorang (Kozier et al, 2004). Latihan ROM adalah latihan pergerakan rentang semua sendi dalam rentang normalnya yang perlu dilakukan secara intensif untuk mempertahankan tonus dan fungsi otot, mencegah disabilitas sendi dan membantu perbaikan fungsi motorik (Hickey, 2003 : Astrid et al, 2011). Rentang gerak dibedakan menjadi dua yaitu rentang gerak pasif dan rentang gerak aktif. Rentang gerak aktif adalah klien dapat menggerakkan sendinya secara mandiri atau tanpa bantuan. Sedangkan rentang gerak pasif adalah klien tidak dapat menggerakkan sendinya secara mandiri dan perawat menggerakkan setiap sendi dengan rentang gerak atau berada diantaranya (Widuri, 2010). Latihan ROM aktif pada lansia tersebut yaitu membimbing lansia dalam melaksanakan pergerakan secara mandiri sesuai dengan rentang gerak sendi normal. Pemberian ROM aktif dilakukan selama 30 menit selama satu minggu tiga kali untuk meningkatkan kekuatan otot dan memberi kesehatan fisik pada lansia (Imron et al, 2015).

Selain latihan ROM dan kelemahan yang dialami, faktor usia mempengaruhi kenaikan kekuatan otot berhubungan dengan rehabilitasi. Proses rehabilitasi pasien adalah proses pembelajaran motorik yang merupakan sekumpulan proses yang mempengaruhi latihan motorik dalam keadaan internal dari 
sistem saraf pusat. Latihan ROM dilakukan melibatkan ingatan jangka panjang dan pasien lebih mudah belajar. Usia tua diketahui memiliki kemampuan ingatan jangka panjang yang kurang dibanding usia muda, jadi usia memiliki dampak pada kemampuan pemulihan kekuatan otot (Rhestifujiyanti et al, 2015).

\section{METODE PENELITIAN}

Desain: Penelitian ini merupakan penelitian kuantitatif dengan desain pra experiment dengan metode one group pretest-posttest design, Sampel: Pengambilan sampel dilakukan dengan cara purposive sampling sebanyak 6 orang. Analisa data: Penlitian ini menggunakan uji univariat dan bivariat. Hasil uji normalitas pada penelitian ini menunjukkan bahwa data terdistribusi normal sehingga digunakan uji Paired t-test untuk analisa bivariat dengan batas derajat kemaknaan $p<$ 0.05. Lansia yang mengalami gangguan fungsional otot dan sendi berjumlah 29 orang, responden yang Mengalami gangguan berjumlah 10 orang Setelah dilakukan pengecekan kartu riwayat Ada 3 orang lansia yang menderita hipertensi sehingga jumlah responden dalam penelitian ini berjumlah 7 orang. Namun saat dilakukan penelitian terdapat 1 orang lansia tidak mampu mengikuti latihan ROM aktif. Sehingga jumlah responden dalam penelitian 6 orang. Instrument: Alat pengumpulan data yang digunakan adalah Lembar SOP latihan range of motion, lembar check list latihan range of motion, lembar observasi kekuatan otot, lembar penuntun manual muscle test.

\section{HASIL PENELITIAN}

Pengaruh Latihan Range of Motion (ROM)

Aktif Terhadap Peningkatan Kekuatan

Otot Ekstremitas Bawah Pada Lansia di PSTW Kasih Sayang lbu Batusangkar Tahun 2018

Hasil analisa data pengaruh latihan Range Of Motion (ROM) aktif terhadap peningkatan kekuatan otot ekstremitas bawah pada lansia di PSTW Kasih Sayang lbu Batusangkar dalam tabel 5.3 berikut ini :

Pengaruh Latihan Range of Motion (ROM) Aktif Terhadap Peningkatan Kekuatan Otot Ekstremitas Bawah Pada Lansia di PSTW Kasih Sayang Ibu Batusangkar

\begin{tabular}{|c|c|c|c|c|c|c|c|}
\hline Regio & Intervensi & $\mathbf{N}$ & Mean & $\begin{array}{l}\text { Standar } \\
\text { Deviasi }\end{array}$ & $\begin{array}{c}\text { Mean } \\
\text { Difference }\end{array}$ & $\begin{array}{l}\text { Standar } \\
\text { Deviasi }\end{array}$ & $\begin{array}{c}\text { P. } \\
\text { Value }\end{array}$ \\
\hline \multirow[t]{2}{*}{ Hip } & Pre Test & 6 & 3,03317 & 0,085080 & & & \\
\hline & Post Test & 6 & 3,22117 & 0,194376 & $-0,188000$ & 0,150439 & 0,028 \\
\hline \multirow[t]{2}{*}{ Knee } & Pre Test & 6 & 3,44433 & 0,245342 & \multirow{2}{*}{$-0,319333$} & \multirow{2}{*}{0,133618} & \multirow{2}{*}{0,002} \\
\hline & Post Test & 6 & 3,76367 & 0,226246 & & & \\
\hline \multirow[t]{2}{*}{ Ankle } & Pre Test & 6 & 3,24300 & 0,089192 & \multirow{2}{*}{$-0,270833$} & \multirow{2}{*}{0,131038} & \multirow{2}{*}{0,004} \\
\hline & Post Test & 6 & 3,51383 & 0,176079 & & & \\
\hline \multirow[t]{2}{*}{ Toe } & Pre Test & 6 & 3,31950 & 0,133389 & \multirow{2}{*}{$-0,548500$} & \multirow{2}{*}{0,084998} & \multirow{2}{*}{0,000} \\
\hline & Post Test & 6 & 3,86800 & 0,124898 & & & \\
\hline
\end{tabular}


Tabel diatas menunjukkan bahwa rata-rata kekuatan otot ekstremitas bawah pada lansia sebelum intervensi ROM adalah rata rata regio hip 3,03317 dengan standar deviasi (SD) 0,085080, sedangkan setelah intervensi ROM adalah 3,22117 dengan standar deviasi (SD) 0.194376. Rata-rata pengaruh kekuatan otot pada lansia di PSTW Kasih Sayang lbu Batusangkar antara sebelum dan sesudah intervensi ROM adalah $-0,188000$ dengan standar deviasi 0,150439. Hasil uji statistik nilai P-Value adalah 0,028. Rata rata regio knee sebelum intervensi 3,44333 dengan standar deviasi (SD) 0,245342, sedangkan setelah intervensi ROM adalah 3,76367 dengan standar deviasi (SD) 0.226246. Rata-rata pengaruh kekuatan otot pada lansia di PSTW Kasih Sayang Ibu Batusangkar antara sebelum dan sesudah intervensi ROM adalah $-0,319333$ dengan standar deviasi 0,133618 . Hasil uji statistik nilai P-Value adalah 0,002 . Rata rata regio ankle sebelum intervensi 3,24300 dengan standar deviasi (SD) 0,089192, sedangkan setelah intervensi ROM adalah 3,51383 dengan standar deviasi (SD) 0,176079 . Rata-rata pengaruh kekuatan otot pada lansia di PSTW Kasih Sayang Ibu Batusangkar antara sebelum dan sesudah intervensi ROM adalah - 0,270833 dengan standar deviasi 0,131038 . Hasil uji statistik nilai P-Value adalah 0,004. Rata rata regio toe sebelum intervensi 3,31950 dengan standar deviasi (SD) 0,133389, sedangkan setelah intervensi ROM adalah 3,86800 dengan standar deviasi (SD) 0,124898 . Rata-rata pengaruh kekuatan otot pada lansia di PSTW Kasih Sayang Ibu Batusangkar antara sebelum dan sesudah intervensi ROM adalah $-0,548500$ dengan standar deviasi 0,084998. Hasil uji statistik nilai P-Value adalah 0,000 . Hasil uji statistik menunjukkan bahwa terdapat pengaruh latihan Range Of Motion (ROM) aktif terhadap peningkatan kekuatan otot ekstremitas bawah pada lansia di PSTW Kasih Sayang Ibu Batusangkar Tahun 2018.

\section{PEMBAHASAN}

Penelitian ini bertujuan untuk mengetahui pengaruh range of motion (ROM) aktif terhadap peningkatan kekuatan otot ekstremitas bawah lansia. Penelitian dilakukan sebanyak 6 kali latihan selama 3 minggu dengan frekuensi untuk 1 kali latihan adalah 2 kali dalam sehari yaitu selama 10 menit. Berdasarkan penelitian yang dilakukan didapatkan rata rata kekuatan otot pada lansia antara sebelum dan sesudah intervensi ROM adalah rata rata sebelum intervensi regio hip 3,03317 dengan standar deviasi (SD) 0,085080, sedangkan setelah intervensi ROM adalah3,22117 dengan standar deviasi (SD) 0.194376. Rata-rata pengaruh kekuatan otot pada lansia di Panti jompo antara sebelum dan sesudah intervensi ROM adalah -0,188 dengan standar deviasi 0,150439 . Hasil uji statistik nilai P-Value adalah 0,028 . Rata rata regio knee sebelum intervensi 3,44333 dengan standar deviasi (SD) 0,245342 , sedangkan setelah intervensi ROM adalah 3,76367 dengan standar deviasi (SD) 0.226246 . Rata-rata pengaruh kekuatan otot pada lansia antara sebelum dan sesudah intervensi ROM adalah -0,319333 dengan standar deviasi 0,133618 . Hasil uji statistik nilai P-Value adalah 0,002 . Rata rata regio ankle sebelum intervensi 3,24300 dengan standar

deviasi (SD) 0,089192, sedangkan setelah intervensi ROM adalah 3,51383 dengan standar deviasi (SD) 0,176079. Rata-rata pengaruh kekuatan otot pada lansia antara sebelum dan sesudah intervensi ROM adalah - 
0,270833 dengan standar deviasi 0,131038. Hasil uji statistik nilai P-Value adalah 0,004. Rata rata regio toe sebelum intervensi 3,31950 dengan standar deviasi (SD) 0,133389, sedangkan setelah intervensi ROM adalah 3,86800 dengan standar deviasi (SD)0,124898. Rata-rata pengaruh kekuatan otot pada lansia antara sebelum dan sesudah intervensi ROM adalah $-0,548500$ dengan standar deviasi 0,084998. Hasil uji statistik nilai P-Value adalah 0,000 . Artinya kekuatan otot responden pada lansia setelah dilakukan latihan range of motion meningkat dari sebelumnya.

Secara teori, apabila otot-otot termasuk otot ekstremitas bawah tidak dilatih terutama pada klien yang mengalami gangguan fungsi motorik kasar dalam jangka waktu tertentu maka otot akan kehilangan fungsi motoriknya secara permanen. Hal ini terjadi karena otot cenderung dalam keadaan immobilisasi. Keterbatasan immobilisasi mempengaruhi otot klien melalui kehilangan daya tahan, penurunan masa otot, atrofi dan penurunan stabilitas. Pengaruh lain dari keterbatasan mobilisasi adalah gangguan metabolism kalsium dan gangguan mobilisasi sendi. Immobilisasi dapat mempengaruhi fungsi otot dan skeletal. Akibat pemecahan protein pada otot, klien mengalami kehilangan masa tubuh yang membentuk sebagian otot (Potter \& Perry, 2006).

Oleh karena itu penurunan masa otot tidak mampu memepertahankan aktifitas tanpa peningkatan kelelahan. Masa otot menurun akibat metabolism dan otot yang tidak digunakan. Jika immobilisasi berlanjut dan otot tidak dilatih maka akan terjadi penurunan masa yang berkelanjutan (Potter \& Perry, 2006). Penurunan mobilisasi dan gerakan mengakibatkan kerusakan muskuloskeletal yang besar dengan perubahan patofisiologi utamanya adalah atrofi. Atrofi adalah suatu keadaan sebagai respons terhadap penyakit dan penurunan aktifitas sehari-hari seperti pada immobilisasi dan tirah baring (Kasper et al, 1993 dalam Potter \& Perry, 2006). Penurunan stabilitas terjadi akibat kehilangan daya tahan, penurunan masa otot, atrofi dan kelainan sendi yang actual sehingga klien tidak mampu bergerak terus-menerus dan beresiko untuk jatuh.

Pada penelitian Widya Yuwitri (2016) mengenai Pengaruh Latihan ROM Aktif-asistif (Spherical Grip) Terhadap Kekuatan Otot Ekstremitas Atas Pasien Stroke Non Hemoragik di Ruangan Neurologi RSUD Dr. Achmad Mochtar Bukittinggi Tahun 2016 didapatkan hasil bahwa ada perbedaan rata-rata kekuatan otot sebelum dan sesudah dilakukan latihan ROM, dengan nilai $p=0,029$. Hasil penelitian ini juga didukung oleh penelitian yang dilakukan oleh Hasyim (2013) yang mengatakan bahwa latihan ROM yang dilakukan sedini mungkin dan dilakukan dengan benar dan secara terus-menerus akan memberikan dampak pada fleksibilitas sendi, kekuatan otot dan kemampuan fungsional pasien.

Penelitian ini sejalan dengan penelitian yang dilakukan oleh Safa"ah (2010) dengan judul pengaruh latihan range of motion terhadap peningkatan kekuatan otot lanjut usia di UPT pelayanan sosia lanjut usia (Pasuruan) Kec. Babat Kab Lamongan didapatkan peningkatan kekuatan otot yang berarti pada lansia setelah diberikan perlakuan berupa latihan ROM. Pada kelompok eksperimen, sebagian besar $(58 \%)$ responden terdapat peningkatan kekuatan otot antara pre-test dan post- test, sedangkan hampir setengahnya (26\%) responden tidak terdapat penurunan 
antara pre-test dan post-test atau dikatakan tetap, sebagian kecil (16\%) responden terdapat penurunan antara pre-test dan post test.

\section{KESIMPULAN}

Penulis menganalisa penelitian di atas, bahwa Range Of Motion (ROM) jika dilakukan sedini mungkin dan dilakukan dengan benar dan secara terus-menerus akan memberikan dampak pada kekuatan otot. Latihan ROM ratarata dapat meningkatkan kekuatan otot serta pengaruh dari kekuatan otot. Pemberian metode range of motion aktif ini bertujuan untuk melatih kelenturan dan kekuatan otot serta sendi dengan cara menggunakan otot ototnya secara aktif atau mandiri sehingga menjadi lebih efektif dalam upaya meningkatkan kekuatan otot. Berdasarkan hasil analisa diatas didapatkan adanya pengaruh latihan Range Of Motion (Aktif) Aktif terhadap peningkatan kekuatan otot ekstremitas bawah pada lansia di PSTW Kasih Sayang lbu Batusangkar.

\section{DAFTAR PUSTAKA}

Astrid et al. 2011. "Pengaruh Latihan Range Of Motion (ROM) Terhadap Kekuatan Otot, Luas Gerak Sendi, Dan Kemampuan Fungsional Pasien Stroke di RS Sint Carolus Jakarta". Jurnal Keperawatan dan Kebidanan. Vol. 1, No. 4, Juni 2011 : 175-182.

Chaidir \& Zuardi. 2014. "Pengaruh Latihan Range Of Motion Pada Ekstremitas Atas Dengan Bola Karet Terhadap Kekuatan Otot Pasien Stroke Non Hemoragi Di Ruang Rawat Stroke RSSN Bukittinggi Tahun 2012”. „Afiyah Vol 1 No 1 Januari 2014.

Depkes, RI. 2015. Demografi Populasi Penduduk Lanjuut Usia di Dunia dan Indonesia. Jakarta.
Dewi. 2014. Buku Ajar Keperawatan Gerontik. Yogyakarta : Deepublish.

Imron et al. 2015. "Pengaruh Latihan ROM Aktif

Terhadap Keaktifan Fisik Pada Lansia di Dusun Karang Templek Desa Andongsari Kecamatan Ambulu Kabupaten Jember". Jurnal Edu Health. Vol. 5, No. 1, April 2015.

Kozier, et al. 2004. Fundamental of Nursing : Conceps, Process, and Practice (7th Ed.). Jakarta : EGC.

Kurnia. 2017. "Pengaruh Pemberian Terapi Latihan dengan Metode Proprioceptive Neuromuscular Facilitation Untuk Meningkatkan Kekuatan Otot Ekstremitas Bawah Pada Pasien Stroke Non Hemoragik di RSSN Bukittinggi Tahun 2017". (skripsi). Bukittinggi : Program Studi IImu Keperawatan, Stikes Fort De Kock Bukittinggi.

Lukman \& Ningsih. 2011. Asuhan Keperawatan pada Klien dengan Gangguan Sistem Muskuloskeletal. Jakarta : Salemba Medika.

Maimurahman, et al. 2012. "Keefektifan Range Of Motion (ROM) Terhadap Kekuatan Otot Ekstremitas Pada Pasien Stroke". Jurnal IImu Keperawatan.

Mudrikhah. 2012. "Pengaruh Latihan Range Of Motion Aktif Terhadap Peningkatan Rentang Gerak Sendi Dan Kekuatan Otot Kaki Pada Lanjut Usia Di Panti Werda Dharma Bakti Surakarta". Jurnal Keperawatan Fakultas IImu Kesehatan Universitas Muhammadiyah Surakarta.

Muttaqin. 2011. Buku Ajara Asuhan Keperawatan Klien dengan Gangguan Sistem Persarafan. Jakarta : Salemba Medika. 
Nugroho. 2008. Keperawatan Gerontik dan Greiatrik. Edisi 2. Jakarta : Penerbit Buku Kedokteran EGC.

Olviani, et al. 2017. "Pengaruh Latihan Range Of Motion (ROM) Aktif - Asistif (Spherical Grip) Terhadap Peningkatan Kekuatan Otot Ekstremitas Atas Pada Pasien Stroke Di Ruang Rawat Inap Penyakit Syaraf (Seruni) RSUD Ulin Banjarmasin". Dinamika Kesehatan Vol 8 No 1 Juli 2017.

Potter \& Perry. 2005. Buku Ajar Fundamental Keperawatan : Konsep, Proses, dan Praktik. Edisi 4. Jakarta : Penerbit Buku Kedokteran EGC.

Pudjiastuti \& Utomo. 2003. Fisioterapi Pada Lansia. Jakarta : Penerbit Buku Kedokteran EGC.

Rhestifujiyanti et al. 2015. "Comparison of Muscle Strength in Stroke Patients Between The Given And Not Given Range Of Motion Exercise". Nurse Media Journal of Nursing. Vol. 5, No. 2, 2015.

Safaah et al. 2017. "Effectiveness Of Isometric And Range Of Motion (ROM) Exercise Toward Elderly Muscle Strenght In Pasuruan Integrated Service Unit, Elderly Social Service In Lamongan. Journal Biomedical Engineering. Vol. 3, No. 1, 2017.

Sahmad et al. 2016. "Pengaruh Pemberian Range Of Motion (ROM) Pasif Terhadap Peningkatan Fleksibilitas Sendi Pada Lansia Di Panti Sosial Tresna Werdha Minaula Kendari". Jurnal Kesehatan Manarang. Vol. 2, No. 2, Desember 2016: 2528-5602. (21 Oktober 2017).
Stanley \& Beare. 2007. Buku Ajar Keperawatan Gerontik. Edisi 2. Jakarta : Penerbit Buku Kedokteran EGC.

Sugiyono. 2007. Metode Penelitian Kuantitatif, Kualitatif dan R\&D. Bandung : Alfabeta.

Sukmaningrum. 2012. "Efektivitas Range Of Motion (ROM) Aktif - Asitif : Spherical Grip Terhadap Peningkatan Kekuatan Otot Ekstremitas Atas Pada Pasien Stroke Di RSUD Tugurejo Semarang". Jurnal Keperwatan 2012.

Tamher \& Noorkasiani. 2009. Kesehatan Usia Lanjut dengan Pendekatan Asuhan Keperawatan. Jakarta : Salemba Medika.

Tseng et al. 2007. "Effect Of A Range Of Motion Exercis Programme". Journal of Advanced Nursing 57(2), 181-191.

Uda et al. 2016. "Latihan Range Of Motion Berpengaruh Terhadap Mobilitas Fisik pada Lansia di Balai Pelayanan Sosial Tresna Werdha Unit Abiyoso Yogyakarta". Jurnal Ners dan Kebidanan Indonesia. Vol. 4, No. 3, Tahun 2016 : 169-177

Wahyuningsih et al. "Pengaruh Range Of Motion Aktif (Clyndrical Grip) Terhadap Kekuatan Otot Ekstremitas Atas Pada Pasien Stroke Non Hemoragik". Jurnal Ilmu Keperawatan.

Yuwitri. 2016. "Pengaruh Latihan ROM AktifAsistif (Spherical Grip) Terhadap Kekuatan Otot Ekstremitas Atas Pasien Stroke Non Hemoragik di Ruangan Neurologi RSUD Dr. Achmad Mochtar Bukittinggi Tahun 2016". (Skripsi) . Bukittinggi : Program IImu Keperawatan, Stikes Fort De Kock Bukittinggi. 